\title{
BRANDING AND BRAND MANAGEMENT IN INTERNATIONAL BUSINESS
}

\author{
Ljiljana Stošić Mihajlović ${ }^{1}$, Svetlana Trajković \\ ${ }^{1.2}$ Academy of Applied Technical and Preschool Studies, Niš \\ stosicmihajlovicljiljana@gmail.com, cecasvtr@yahoo.com
}

\section{Professional Paper 10.5937/jouproman8-26139}

\begin{abstract}
Marketing is a scientific discipline oriented to practice, and is of particular importance for the functioning of business systems and organizations in the market economy, especially in modern secure business conditions and conditions of market globalization, strong competition in all business spheres, which is one of the main characteristics for the market in the Republic. Serbia.

Creating, or creating and successfully developing a brand that can be equally involved with the world's leading brands in the fight for consumers, both in the domestic market and in other markets, becomes a major factor and key to the success of modern business and contemporary organizations of the world of work. Therefore, the aim of this paper is to point out the importance of brand management, through related units to guide in the specifics of brand building with an overview of relevant and present current concepts and examples, to bring closer to various aspects of brand management, with a special focus on the situation in Serbia and in our the immediate environment.
\end{abstract}

Keywords: brand management, branding, international business

\section{Introduction}

With the development of the economy and society, there is an expansion of the marketing of the sector, so that it has become a dominant force in business corporations in developed countries. Due to the importance of marketing activities for business excellence and lasting competitive advantage, in national economies, but also 38 because of the specific nature of services and business in different industries, marketing is a special area of application of science in business practice, which therefore requires a special approach. The goal of brand management, as the most creative segment of marketing practice, is to direct or inform market participants in the specifics of marketing application in the growing service sector, and to show them how to put into practice the marketing philosophy of thinking and doing business in this field.

A structured approach to brand management should demonstrate concepts, but above all practical application, it is very useful for all those who work in the marketing sector or are trained in marketing jobs. Brand management has applications in banking, insurance, consulting, wholesalers, retail chains, telecommunications, hospitality, hospitality, education, or any other growing area of the service business, which tends to become a well-rounded concept of marketing and thinking in the marketing sector. By applying the acquired knowledge, brand management takes a look at the business and drives things around the organization for the better. 


\section{About brand management}

„We can conclude that international business is, in conceptual terms, a broader term than international marketing. The reason lies in the fact that international business encompasses all business functions (production, finance, personnel) while international marketing involves concentrating on the variables of the marketing mix instruments. The following figure shows the concept of international business management. “1

Today it is safe to say that brands are an increasingly important part of the business cultures of contemporary organizations in the world of work. It is a notorious fact that brands help and make it easy for people to make choices and decisions, both small and large, that is essential. Thanks to the brand, we can say with almost $100 \%$ certainty that there is a great deal of confidence in the wine we drink, the Mercedes we drive, the Adidas sneakers we wear on the run, and in a number of other products we use on a daily basis, both for consumer and reproduction consumption. A brand is a concept, idea, perception, expectation and belief that arises in the minds of consumers (existing or potential customers) or any individual who can influence an organization's business competence.

The conditions of life today are such that we can say that we live in an interconnected world, which with the development of a growing number of new information and communication technologies has become

${ }^{1}$ Stošić Mihajlović, Lj., Trajković, S. (2020) The importance of marketing instruments for market approach and operation of export companies. (JPMNT) Journal of Process Management - New Technologies, International Vol. 8, No 1, pp.19 transparent. In contemporary business conditions, even an individual is exactly the way the organization has become a brand, and they have become more accessible and exposed to the watchful eye of the world's citizens. Strong brands lead to creating awareness. They make it possible for the public to judge, that is, the general public can understand on a brand basis both the spirit of the corporation and the promise it offers to some of its brand.

Customer understanding of the brand is dominant in the business world. Customers now have greater access to and even control over the information on which they build their perception of a brand. The ideas and impressions that the company assumes that customers are nurturing about its productbrands are in the throes of competing ideas, which are also struggling for their own better market opportunity.

\section{International knowledge brands and attitudes of world-known brand managers}

We are living in a new age of consumerism, characterized by a transformation into a new, higher form of relationship and responsibility towards the brand. In the business world, examples such as Enron have led to greater consumer confidence in information coming from brands and companies. Namely, it is a business environment that we call a new term: ecology. This term means that the brand, the company or its leaders, or managers, cannot hide behind inaccurate ideas and half-truths, because the truth about a company or its product will always be revealed. 
There is no longer any possibility, that is, there is no option to remain silent about the values, mission or relevance of the company. Even when a company operates locally, that is, with only local consumers, information availability and transparency, it makes all brands undergo a thorough global review and evaluation.

It can be said that the best are those brands that persistently win in two key moments. First, when consumers select, separate or sign a contract to purchase a product or service, after evaluating other competing offers. Secondly, appearing in consumers' homes, offices or product halls, when they use a brand, try it out and be pleased with it or not. Brands that persist in these two moments gain a special place in the minds and hearts of consumers. These brands are remembered and much easier and more profitable to buy again. The value of the trust gained between the promise the brand offers and the experience gained from using it is always a quality basis for a viable commercial endeavor.

Some industry brands are intensely focused on conquering the foregoing moments of truth. This is accomplished by always being in touch with customers and consumers, understanding and understanding their design and implementation requirements, and their brand expectations. Clearly, brands like IBM are not only relevant to large computer servers or IT software, but also for the business of banks or airlines 24 hours a day 365 days a year. Epl (Apple) is technology; and it is also a brand that is constantly thinking in a different way. Procter \& Gemble $(\mathrm{P} \& \mathrm{G})$ goes beyond simply manufacturing personal care and household hygiene products, as it affects the quality of life itself by promoting it.
Audi moves things - the individual, life, world or space through which it travels.

Many of the brands mentioned have flourished after their managers listened to speeches or lectures by Philip Kotler or Waldemar Pfoertsch. Managers have at their disposal insights that can be read in the books and works of the aforementioned authors. They return to their jobs, encouraged to apply the new management principles. Philip Kotler's passionate belief in marketing and brand management is inspiring and effective. It helps us re-think the way we think about creating and nurturing our own brands.

Focused branding brings us closer to customers. In this direction, Professor Kotler encourages us to seek greater differentiation, but without neglecting our competition, and encourages us to constantly focus our top management's attention on branding and branding decisions.

According to Tim Love, Vice President, Omnicom Group, "Branding is a very important part of all cultures around the world and an indispensable part of the business world."

Axel C. Heitmann, CEO of Lanxess, on the other hand, says: "The globalization of economic exchange and the disappearance of interstate borders are well known to $21 \mathrm{st}$ century business leaders ... the book will give you knowledge on how to differentiate your company in the global competition market. 
Achim Kuhn, head of marketing at Herrenknecht says the relevance of branding is obvious. However, the biggest barrier to professional branding is the spirit of branding that needs to be instilled in the minds of business decision makers. Branding can then gain momentum. This book will be very helpful to those responsible for this process.

Bill Amelio, CEO of Lenovo says that at Lenovo, we believe that branding is as important as branding in the Business to Consumer arena. They combine a methodological approach to B2B branding and a wealth of examples of practice.

\section{Branding - the process of building a brand}

„In modern conditions, many universities and colleges in the world provide study programs in the field of communications and relations with the target market public. This is because the marketing profession is reputable and provides opportunities for rapid advancement and the pursuit of ambitions that are characteristic of the human race. People doing market research and marketing are optimistic, cheerful, curious, courteous and dedicated people who literally enjoy their jobs. Related to this is their positive attitude towards the media, which stems from their desire to be aware of everything that is happening in the organizations of the world of work, and beyond, in all areas of human activity. “2

At the organizational level, it is necessary to develop a branding strategy, which is essentially a long-term plan for developing

\footnotetext{
${ }^{2}$ Stošić Mihajlović, Lj. Trajković, S. (2020). Market survival conditions under constant marketing mobility, (JPMNT) Journal of Process Management - New Technologies, International Vol. 8, No 1, pp. 24
}

a successful brand, with the aim of achieving certain market success. A welldefined and executed branding strategy influences all aspects of the business, so much so that it is directly linked to customer needs, consumer experiences and competition. Essentially, it is a marketing strategy that involves creating a differentiated (specific) name and image, most commonly through logos and / or slogans, for the purpose of gaining recognition in consumer awareness and attracting and / or retaining customers.

Branding is not just about specifying a target market and selecting a product and / or service that is differentiated from the competition. Branding refers to seeing the product being offered to potential customers as the only provider and the only one offering a quality solution to their problems or needs.

The goals that a good brand needs to achieve are:

- sending a clear message to customers,

- authentication,

- emotionally connecting the market with a product and / or service,

- achieving consumer loyalty,

- motivate consumers to buy a product and / or service.

In order for a branding strategy to succeed, it must start from understanding the needs and wants of its customers. This is achieved by integrating the branding strategy into every form of communication between the company and the market, because branding is an expression of what the firm offers. Every product and / or service that a company offers has its own lifetime. But the brand is something that goes beyond the product. The brand is the value that stays alive despite the product, so it is important to build a branding strategy. 
The importance of branding is numerous, but the most important is that it can help increase sales. This means that when needed e.g. increase product prices, the target population will accept price increases because the brand is what they value. Branding also develops the uniqueness of a product and / or service and encourages confidence and confidence in a particular product and / or service even in cases where production does not live up to expectations.

\section{Steps in branding}

"In the modern world, everything is for sale, starting from goods and services, through ideas and information, to people, as experts in certain jobs. Nothing is out of the market system, and a well-known password that "everyone and everyone has their price", it seems that before, as it is now, it has its full valorization. Why is it so and why are people trying to get everything they have to market, or is this behavior the result of a general race for profit? Perhaps people evolved in their endeavors to get economically as soon as possible and occupy the best market position. In that sense, the fact is that there is really little chance of winning a superior financial position."3

There are a number of instructions in the marketing literature on how to build a brand. One can say that there are as many branding strategies as there are authors who have written about it. However, everyone generally agrees that the company moves to the brand in the following steps:

1. Designing a brand strategy for a company, product or service - "A brand

3 Stošić Mihajlović, Lj., Trajković, S., (2019). Agressive vs. discrete marketing, (JPMNT) Journal of Process Management - New Technologies, International, Vol.7, No 2, pp.7

42 strategy is made after a detailed analysis of the product itself, consumer analysis for which it is intended (their lifestyle, habits, attitudes ...), competition and market analysis, market position analysis competing brands and their communications with consumers and the general public. During this process, the brand strategist seeks to find the specific benefits that the new brand provides to the consumer as well as the range of values that the new brand represents. Based on this, the brand image of the product is built and its unique position is found in the market and in the minds of the consumers. " )

2. Designing a Visual Identity for a Brand - A new brand is like a tabula of races, it has its own uniqueness and character that has yet to develop in the years to come. His brand name should match his character and faithfully portray him, as well as his visual identity. The unique name and unusual and striking design will draw the audience's attention to the brand and influence the consumer's decision to opt for it.

3. Designing a Communication Strategy A brand is built by communication and in order for communication to succeed, we need to know the market. The message that reaches the consumer must be unambiguously clear and must come at the moment when he or she is most in the mood to receive it. We can send a message to print or electronic media, in virtually any place. Modern ICT provides numerous opportunities for us to get in touch with the consumer and only the creativity of the communication team depends on the choice of channels of communication that will lead to the shortest path. 
4. Choosing an Idea - The modern consumer is constantly bombarded with an abundance of information coming from different media. In this regard, it is of great importance to find the answer to the question: How can we influence the consumer to remember the message we are sending him? Each message must be accompanied by an original idea that will evoke a positive emotion for the viewer.

5. Choice of communication channels The success of our promotional activities depends on the proper choice of media, places and situations in which we want to promote the brand, but also the budget that we have to set aside for their realization. Traditional media such as television, billboards and print media cover the widest target audience but are very expensive to implement. Internet campaigns, various promotional and guerrilla campaigns cost much less and can have a very good effect.

6. Monitoring the Effects of Communication - The effects of communication can be measured against the increase in demand and sales of the product itself. Equally important are the effects that communication has on consumers' attitudes and behavior. Regular consumer surveys are necessary to determine the brand recognition, discover consumer attitudes towards a brand, their emotions towards a particular brand, how often, when and how they use the brand, how willing they are to pay for a particular brand, etc.
7. Adaptation to the current market situation - Sometimes the current market situation threatens to significantly jeopardize a brand's position relative to its competition. We are aware of the changes in the market caused by the global economic crisis, the appearance of the flu has caused some products or services to decrease demand (tourist trips) and for others to increase (disinfectants). Sometimes one of the competitors makes a business move that can suddenly jeopardize the status of other players in the market. This is why it is important to constantly monitor the market situation and act in a timely manner to avoid adverse situations or minimize their impact if they are unavoidable.

8. 'Face lifting' of the brand - occurs when market research and consumer attitudes indicate that the modernization of the product / service and / or its image is necessary. This is often the case with products that have been present on the market for a long time or with products that did not have a well-developed branding strategy from the very beginning but still managed to impose their quality on consumers, so now, in order to survive and continue to advance in the market, become complete in a communicative sense. 
9. Brand repositioning - Once established in the market, the brand begins its own life. During its growth and development it is subject to various changes that are affected by market development, social and cultural changes in society, various economic and technological factors, etc. Sometimes changes are big and require the brand to change or modify its position in the market. Coca Cola, for example, was launched in the late 19th century as a means of facilitating digestion; today it is the most popular refreshing drink; Marlboro was originally conceived as a women's cigar and today it is a distinctly male brand. The brand can change its purpose, its target group (contraceptives and sexually transmitted infections are used today by very young teenagers and not just adults), the way it is used (ice cream used to be a seasonal commodity and is eaten all year long), the territory where is distributed (we used to watch exotic fruit only on television and now we can buy it in any major market). All these factors can influence the change of a brand strategy of a product and the need to build a new position in the market and in the minds of consumers.

\section{Conclusion}

Brand building is a lengthy process that requires the teamwork of the people in charge of creating a product or service, the people in charge of marketing, and the team of professionals in charge of communicating and building the brand image of a company product or service. When creating a brand, you should follow the steps, from the idea itself, to the repositioning of the brand. Brand building is a process that requires constant investment that, over the years, as the brand gets more and more fans, returns repeatedly. Many world-renowned brands have become so thanks to the intense efforts of the marketing sector to promote it in terms of positioning the brand in consumer awareness.

\section{References}

[1] Kotler, F., Ferč, V., (2019). B2B brend menadžment. Krug Kommerce. Beograd, str. 127

[2] Stošić Mihajlović, Lj. (2020). Marketing. Akademija tehničko-vaspitačkih strukovnih studija, Niš, str. 98

[3] Manzana strategic branding, Do brenda u 9 koraka, Beograd, str.2.

Dostupno na:

http://manzana.rs/DO\%20BRENDA\%20U\%209\%2 0KORAKA.pdf

[4] Stošić Mihajlović, Lj. Trajković, S. (2020). Market survival conditions under constant marketing mobility, (JPMNT) Journal of Process Management - New Technologies, International Vol. 8, No 1, pp. 24

[5] Stošić Mihajlović, Lj., Trajković, S., (2019). Agressive vs. discrete marketing, (JPMNT) Journal of Process Management - New Technologies, International, Vol.7, No 2, pp.7

[6] Stošić Mihajlović, Lj. Trajković, S. (2020). The importance of marketing instruments for market approach and operation of export companies. (JPMNT) Journal of Process Management - New Technologies, International Vol. 8, No 1, pp. 18 